\title{
P-Li-Be Bearing Pegmatites of the South East Brazil
}

\author{
Essaid Bilal ${ }^{1}$, Adolf Heinrich Horn ${ }^{2}$, Fernando Machado de Mello ${ }^{3}$ \\ ${ }^{1}$ Ecole Nationale Supérieure des Mines de Saint-Étienne, Saint-Étienne, France \\ ${ }^{2}$ IGC-UFMG, Belo Horizonte, Brazil \\ ${ }^{3}$ IA-Departamento de Geociências da UFRRJ, Rio de Janeiro, Brazil \\ Email: bilal@emse.fr, hahorn@gmail.com, fermamll@ufrrj.br
}

Received July 26, 2011; revised November 17, 2011; accepted January 6, 2012

\begin{abstract}
The P-Li-Nb pegmatites are located in the south of Brazil, in the states of Minas Gerais and Espirito Santos. They represent the largest pegmatite fields of Brazil and the richest in precious stones. Two types of pegmatites are characterized by their mineralogical characteristics and tectonic and magmatic relations. The first group occurred during a compressive deformation phase D1 about $582 \mathrm{Ma}$ and $550^{\circ} \mathrm{C}-700^{\circ} \mathrm{C}$ and $4-5 \mathrm{~kb}$. The second pegmatites group was formed during the decompression phase D2 (520 - 500 Ma) of the Brasiliano metamorphic rock fusion. The geochemical parameters of the P-Li-Be bearing pegmatites of the first group show the same trend fractionation, as suggested by the mineralogical composition. The variation of tourmaline and columbite-tantalite composition of the first group game again applies a change of melt composition during the regional development of the pegmatites. A systematic compositional trend seems to suggest a petrogenetic link between the pegmatites of the region. The Fe/ $\mathrm{Mn}$ ratio of tourmaline in samples of the first group shows the same behavior as in columbite-tantalite and garnets. The simple pegmatites are transiting north in the gem-rich pegmatites. The Fe/Mn ratio not only shows qualitatively the fractionation index, the degree of regional development, but also the internal development of the body. The ratio shows a negative correlation with lithium. The $\mathrm{Co}, \mathrm{Zn}$ and $\mathrm{Nb}$ contents are rising at first group, but falling when starting crystallization of garnet, columbite-tantalite, and Behierit.
\end{abstract}

Keywords: Gem Rich Pegmatite; Phosphate; Li; Tourmaline; Beryl; Triphylite; Ferrisiklerite; Heterosite

\section{Introduction}

The Doce River region is located in the central northern part of the Mantiqueira Structural Province, east of São Francisco carton in the eastern Minas Gerais and northwestern Espírito Santo states (Figure 1). This province is represented by Neoproterozoic mobile belts that surrounded the São Francisco cratonic block and is associated to the Brazilian orogeny (600 - $450 \mathrm{Ma})$. These mobile belts reworked the early-Proterozoic basement (high and low-grade metamorphic rocks of Piedade, Paraíba do Sul and Pocrane Complexes; Juiz de Fora, late-Proterozoic supracrustal sequences (Rio Doce group) and enabled the intrusion of granites and pegmatites. Several rare metals and gem mineral rich pegmatites are positioned at the São Tomé foliation plane.

The regional evolution was linked to the GovernadorNorth Guaçuí- and Vitoria shear zones. Two main deformation phases (D1 and D2) pre- and post-dating the pluton emplacement and were developed under amphibolite facies conditions. The first deformation (D1) was responsible for penetrative foliation (solid state) $\mathrm{N} 10^{\circ} \mathrm{W}-30^{\circ} \mathrm{W} /$ middle to high angle and mineral lineation of the host rocks and the granitoids. It affected pre-tectonic granites and con- trolled magmatic foliation the sin-tectonic granitoids.

This foliation, the associated oblique lineation and kinematics studies suggest that sub vertical shear zones were important during the emplacement of these granitoids. The second one was characterized by the cleavage crenulation, boudinage and normal faults and it was associated to extensive phase late- and post-tectonic granitoids.

The recent geochronology study demonstrates existence of two tectono-metamorphic events in this region dated at 590 - $565 \mathrm{Ma}$ and 535 - $520 \mathrm{Ma}$ [2-8].

\section{The Pegmatite Bodies}

The pegmatites of the South East Brazil can be divided into two main groups: Gem and P-Li-Be bearing pegmatites and ceramic pegmatites [9].

The first group (Table 1) is considered the result of fractional crystallization of a sin tectonic Magmatic formed. These magmas are related by melting processes, which, took place during temperature $\left(550^{\circ} \mathrm{C}-700^{\circ} \mathrm{C}\right.$ and $4-5 \mathrm{~kb}$ ). Its main representatives are leucogranites and $\mathrm{P}-\mathrm{Li}-\mathrm{Be}$ bearing pegmatites. The age of intrusion is estimated at about 582 Ma occurred during a compressive 


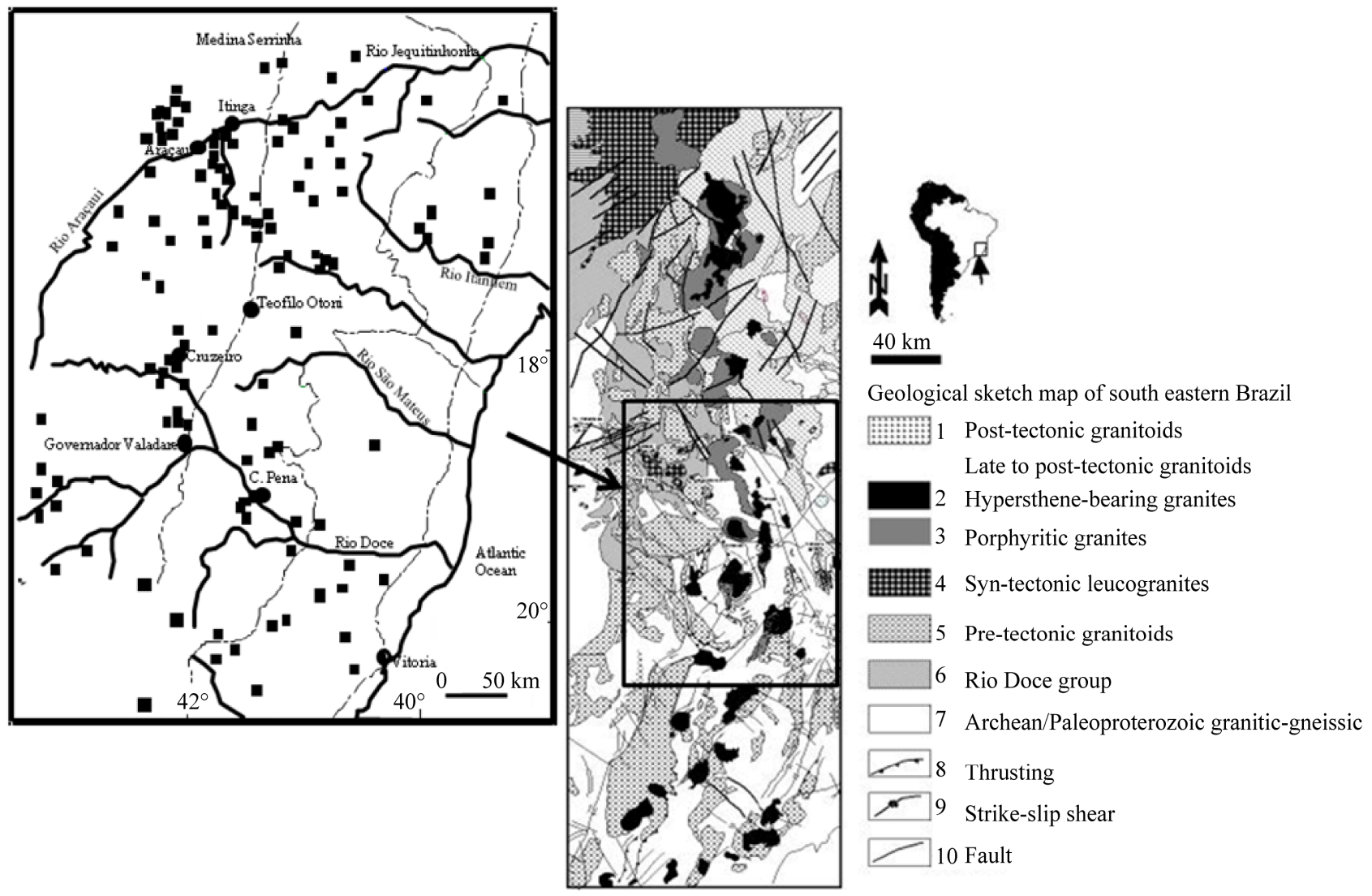

Figure 1. Geological sketch map of south eastern (Compilation data this work and [1-5]).

Table 1. Main characteristics of the first group pegmatites [3].

\begin{tabular}{ll}
\hline Zone & Mineralogy \\
\hline Beryl pegmatite & Quartz, K-feldspar, biotite, muscovite, tourmaline, albite, garnet, beryl, columbite-tantalite (Nb > Ta). \\
Beryl Spodumene Pegmatite & $\begin{array}{l}\text { Quartz, K-feldspar, muscovite, Li-mica, albite, tourmaline gem quality (Figure 2), behierit, mica, beryl, } \\
\text { spodumene, amblygonite, columbite-tantalite }(\mathrm{Nb}=\mathrm{Ta}), \text { cassiterite and the apatite. }\end{array}$ \\
Spodumene Pegmatite & $\begin{array}{l}\text { Quartz, K-feldspar, muscovite, Li-mica, albite, Elbaite, Behierit, garnet, (blue and pink) beryl, spodumene, } \\
\text { amblygonite, columbite-tantalite }(\mathrm{Nb}<\mathrm{Ta}), \text { triphyllite, ferrisiklerite, heterosite, cassiterite and the apatite. }\end{array}$ \\
\hline
\end{tabular}

deformation phase (D1) of Brasiliano orogeny.

Their presence is mainly confined to the area near Governador Valadares, Teófilo Otoni, Araçuaí, Conselheiro Pena and São José da Safira.

The second group (Table 2) was formed during the second phase D2 (520 - 500 Ma) of the Brasiliano metamorphic rock fusion (gneiss migmatite, gneiss). This group is mainly in Espera Feliz, Marilac, Sta. Maria de Itabira and is found in the area around Baixo Guandu.

The main pegmatites bodies show outcropping lengths ranging from $150 \mathrm{~m}$ up to $1300 \mathrm{~m}$ and widths ranging from $10 \mathrm{~m}$ up to $60 \mathrm{~m}$. They are sub vertical bodies striking $\mathrm{N} 10^{\circ} \mathrm{W}-20^{\circ} \mathrm{W}$. The pegmatites outcroppings at different topographic levels, ranging from $150 \mathrm{~m}$ up to 1100 $\mathrm{m}$ into staurolite-garnet schist's and paragneisses concor- dant and discordant to the Brasiliano structures.

Their internal features are in all of them essentially very similar. They show consistent mineral assemblages arising from an internal zoning around the quartz core. The centimetric tourmaline crystals have been collected from the border and the wall zones (black tourmalines), from the intermediate zones (black, green, blue and pink tourmalines) or even from metasomatic pockets (green, blue and pink to red tourmalines). The schorlitic tourmalines are associated with quartz, muscovite, (K, Na)-feldspar, garnet (almandine-spessartite), columbite-tantalite $(\mathrm{Nb}>$ Ta) and prismatic beryl. The elbaitic ones are found together with Na-feldspar (cleavelandite), quartz, amblygonite, spodumene, Li-rich violet micas, morganite, tantalite-columbite $(\mathrm{Ta}>\mathrm{Nb})$ and spessartite garnet [9-11]. 


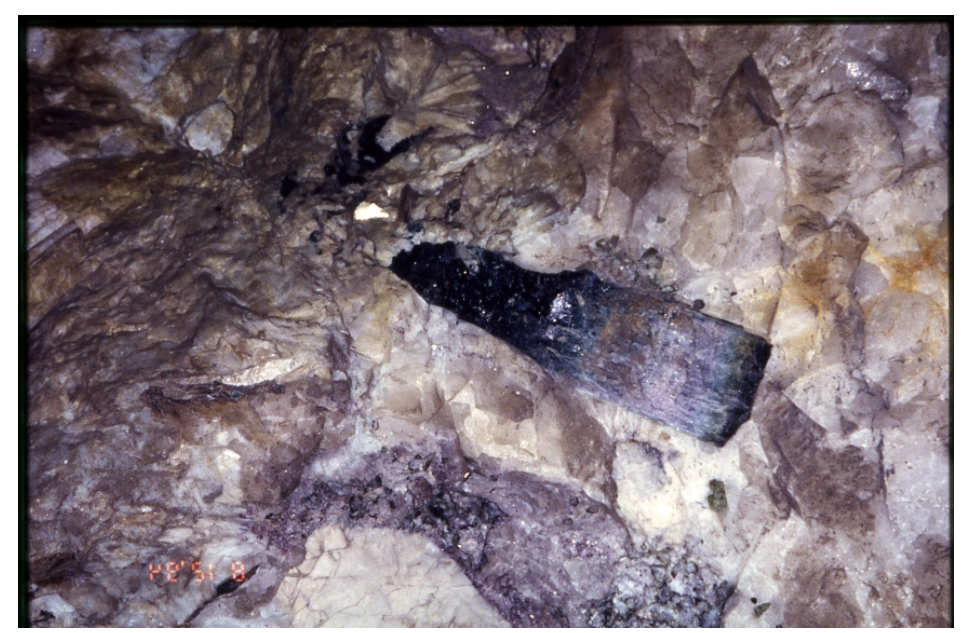

Figure 2. Polychrome tourmaline $(75 \mathrm{~cm})$ in pegmatite (photo by Essaid Bilal).

Table 2. Main characteristics of the second group [3].

\begin{tabular}{|c|c|}
\hline Zone & Mineralogy \\
\hline Contact & Quartz, biotite, K-feldspar, muscovite, albite, fluorite, garnet (almandine-spessartine). \\
\hline Wall & Graphics Quartz, K-feldspar, muscovite, beryl, apatite, monazite (Ce), columbite-tantalite. \\
\hline Intermediary zone & K-Feldspar, Muscovite, Quartz. \\
\hline Core & Quartz. \\
\hline Metasomatic zone & $\begin{array}{l}\text { Amazonite, beryl (construction or pink), cleavelandite (albite), apatite, phosphates }(25 \text { minerals), fluorite, } \\
\text { columbite-tantalite }\left((\mathrm{Fe}, \mathrm{Mn}) \mathrm{Nb}_{2} \mathrm{O}_{6}\right) \text {, euxenite }(\mathrm{Y})\left((\mathrm{Y}, \mathrm{Ca}, \mathrm{Ce}, \mathrm{U}, \mathrm{Th})(\mathrm{Nb}, \mathrm{Ta}, \mathrm{Ti})_{2} \mathrm{O}_{6}\right), \text { Topaz, samarskite } \\
\left((\mathrm{Fe}, \mathrm{Y}, \mathrm{U}, \mathrm{REE})(\mathrm{Nb}, \mathrm{Ta}) \mathrm{O}_{4}\right) \text {, autunite }\left(\left(\mathrm{Ca}\left(\mathrm{UO}_{2}\right)_{2}\left(\mathrm{PO}_{4}\right)_{2}\right) \mathrm{Microlite}\left((\mathrm{Ca}, \mathrm{Na})_{2} \mathrm{Ta}_{2} \mathrm{O}_{6}(\mathrm{O}, \mathrm{OH}, \mathrm{F})\right) \text {, }\right. \\
\text { Wulfenite }\left(\mathrm{PbMoO}_{4}\right) \text {, bismuthinite }\left(\mathrm{Bi}_{2} \mathrm{~S}_{3}\right) \text {, huttonite }\left(\mathrm{ThSiO}_{4}\right) \text { and Kerala }\left((\mathrm{Ca}, \mathrm{Ce}, \mathrm{Th})(\mathrm{P}, \mathrm{Si}) \mathrm{O}_{4}\right) \text {. }\end{array}$ \\
\hline
\end{tabular}

\section{Mineral Chemistry}

The Cs content of mica and $\mathrm{K}$ feldspars from the pegmatites increase continuously; however, the $\mathrm{Rb}$ and $\mathrm{Cs}$ contents (Figure 3) of the 2nd Group are lower than the first group this indicate lower Differentiation of the 2nd Group. There is a positive correlation with $\mathrm{Rb}$ and a negative to $\mathrm{K} / \mathrm{Rb}$. It correlates positively with $\mathrm{Rb}$ and negatively with the ratio $\mathrm{K} / \mathrm{Rb}$. The $\mathrm{Nb}$ contents of micas increases at $160 \mathrm{ppm}$ and decreases after. The pegmatites are the most differentiated ones and show a low fractionation as indicated by high $\mathrm{Na}_{2} \mathrm{O}$ content and high $\mathrm{K} / \mathrm{Cs}$ ratios. This distribution correlates to columbo-tantalite crystallization (Figure 3), the Ta contents increases more in the columbo-tantalite of the first group pegmatites than the 2nd group (rich $\mathrm{Fe}$ and $\mathrm{Nb}$ ).

The curve of the $\mathrm{Fe} / \mathrm{Mn}$ ratio indicates the tourmaline, the first group of pegmatite, a similar pattern as for the micas and columbite-tantalite results $[9,11]$. Take all of the simple pegmatites from the gemstone. This also applies to a regional N-S distribution. The $\mathrm{Fe} / \mathrm{Mn}$ ratio is used as a qualitative marker for the fractionation, both local as well as for internal development (Figure 4). It is correlating negatively with $\mathrm{Li}, \mathrm{Co}$ and $\mathrm{Zn}$ contents in the first group, but begins with the crystallization of $\mathrm{Nb}-\mathrm{Ta}$ minerals, micas, garnet and Behierit to decrease. The ratio $\mathrm{Fe} / \mathrm{Mn}$ of the tourmalines is compared (Figure 4) to those measured in columbo-tantalites and garnets and decreases northwardly continuously from the spodumene bearing pegmatite to Beryl pegmatites; of them bearing not only spodumene but a fine grained $\mathrm{Li}$-rich violet mica too. The infrared spectra of these samples in the principal hydroxyl-stretching region are strikingly different and variation of the $\mathrm{Y}$-site indicating $2 \mathrm{R}^{2+}=(\mathrm{Al}(\mathrm{Y})$ $\left.+\mathrm{Li}^{+}\right)$as the principal substitution mechanism. The $\mathrm{Fe} /$ $\mathrm{Mn}$ ratio has been used as a qualitative fractionation index reflecting not only the regional evolution degree of the pegmatites but the internal evolution of these bodies too. The $\mathrm{Fe} / \mathrm{Mn}$ ratio values correlate negatively with the $\mathrm{Na}$ and $\mathrm{Li}$ contents. The $\mathrm{Fe}, \mathrm{Mn}, \mathrm{Co}$ and $\mathrm{Zn}$ contents begin to increase with the ratio $\mathrm{Fe} / \mathrm{Mn}$, but this growth is disturbed apparently by the beginning of the garnet and columbo-tantalite crystallization.

The LREE contents increase but the HREE contents do not show a definite trend. The abundance and distribution of the REE in tourmalines are mainly controlled by the paragenetic mineral associations. Apatite and garnet fractionation affects the HREE distribution.

\section{Fluid Inclusions}

The Fluid inclusions of quartz and K-feldspar are still 


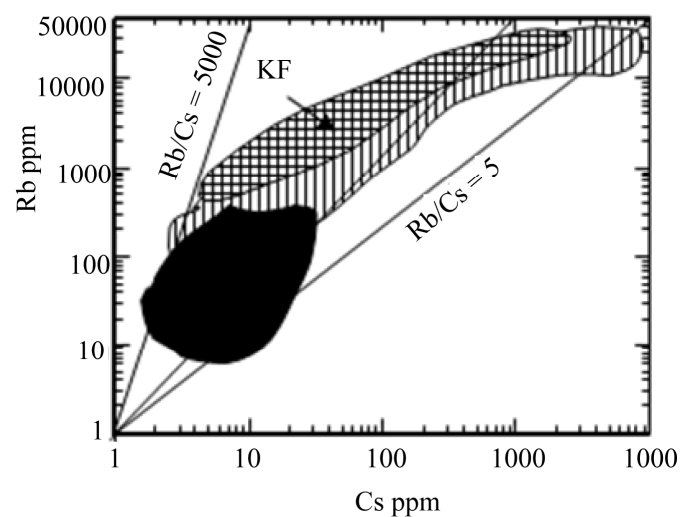

(a)

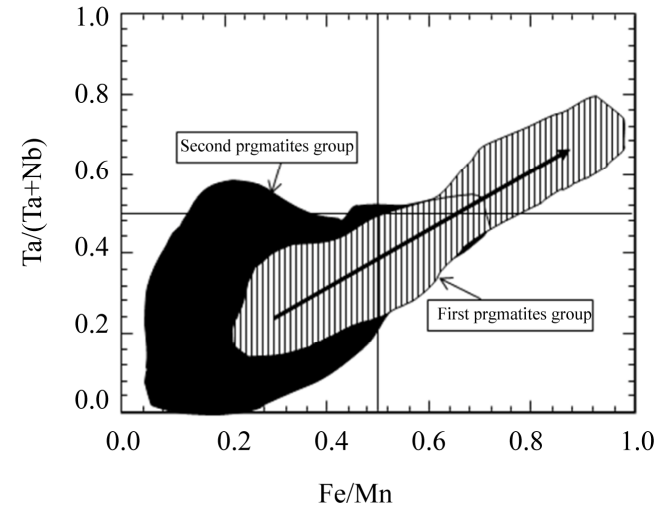

(b)

Figure 3. (a) The Rb/Cs distribution coefficient in mica and K-feldspar shows very low values; (b) Ta/(Ta $+\mathrm{Nb}$ ) versus Fe/Mn of columbo-tantalite. Striped areas: $1^{\text {st }}$ pegmatites Group, Pitch: feldspars of the $1^{\text {st }}$ Group, Black: $2^{\text {nd }}$ pegmatites Group [9, 11,12].

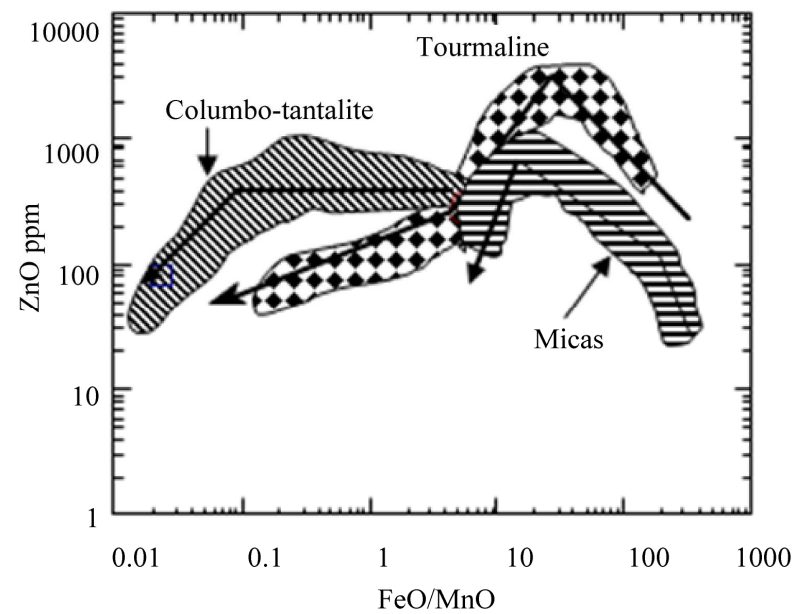

(a)

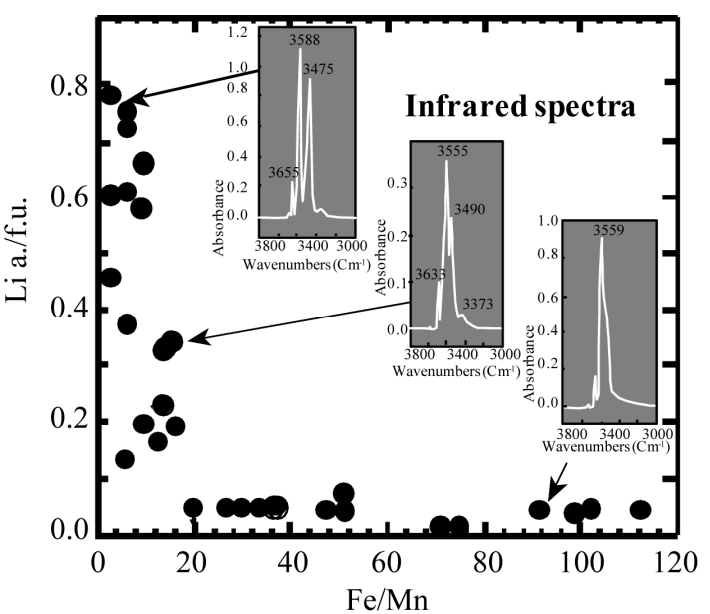

(b)

Figure 4. (a) Fractionation trends of columbite-tantalite, micas and tourmaline in the first Group; (b) The infrared spectra of these tourmaline samples, in the principal hydroxyl-stretching region, show clearly defined absorption peaks at 3474 - 3489 $\mathrm{cm}^{-1}$ and $3373 \mathrm{~cm}^{-1}$.

watery and biphasic. The $\mathrm{CO}_{2}$ accounts for $1 \%$ of the volume of fluid inclusion. The homogenization temperature of water $\left(\mathrm{H}_{2} \mathrm{O} \mathrm{Th}\right)$ is between $100^{\circ} \mathrm{C}$ to $180^{\circ} \mathrm{C}$. Watery fluids were relatively dense $0.87 \mathrm{~g} / \mathrm{cm}^{3}$. The salinity is about $7.8 \%$ weight equivalent $\mathrm{NaCl}$. The melting temperature of $\mathrm{CO}_{2}$ is around $58.5^{\circ} \mathrm{C}$ and the homogenization temperature of $\mathrm{CO}_{2}$ is between $10^{\circ} \mathrm{C}$ and $20^{\circ} \mathrm{C}$ with a density of about $0.85 \mathrm{~g} / \mathrm{cm}^{3}$. Raman spectroscopy confirmed the presence of $\mathrm{CO}_{2}$ and showed the existence of $\mathrm{CH}_{4}$ and $\mathrm{N}_{2}$ in these fluid inclusions.

\section{Hydrothermal and Weathering Process}

Behavior of triphyllite during hydrothermal and weathering processes suggests the following sketch (Table 3):

- Hydrothermal process (triphyllite-ferrisiklerite-heterosite): Under strongest oxidation conditions, the tri- phyllite crystals transforms progressively into ferrisicklerite and the $\mathrm{Li}, \mathrm{Mn}, \mathrm{Mg}$ of triphylite is mobilizing in fluid. The complete leaching of Li into triphylite ends up at the heterosite crystallization. The REE pattern of triphylite (Figure 5) is characterized by a LREE relative enrichment and $\left((\mathrm{Ce} / \mathrm{Yb})_{\mathrm{CN}}=2\right)$ and a negative Eu anomaly $\left(\mathrm{Eu} / \mathrm{Eu}^{*}=0.57\right)$.

- Weathering process (rockbrigeite and beraunite) was characterized by an important hydratation of the heterosite, following the formation of rockbrigeite $(8 \%$ de $\left.\mathrm{H}_{2} \mathrm{O}\right)$ and beraunite $\left(15 \%\right.$ de $\left.\left.\mathrm{H}_{2} \mathrm{O}\right)\right)$ and $\mathrm{Ca}, \mathrm{Na}$, $\mathrm{Mn}$ and $\mathrm{Mg}$ are leaching.

\section{Magmatism Relationship}

We study many little leucogranites body linked to the pegmatites [12]. They are controlled by a previous main 

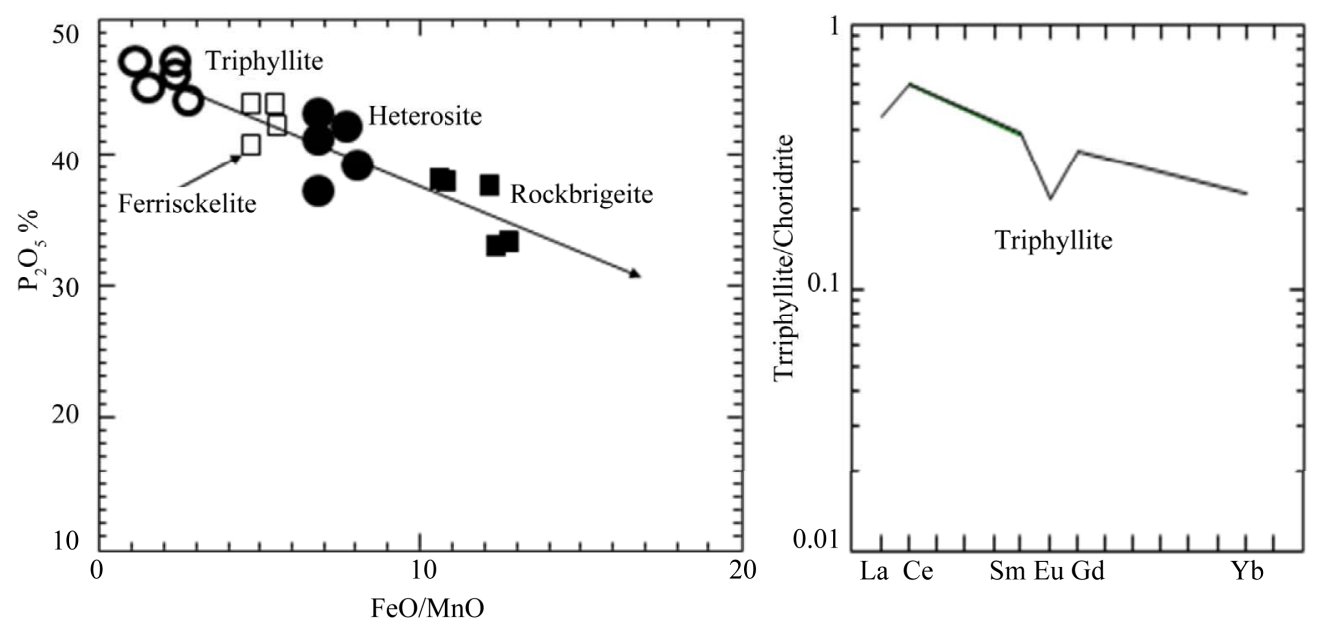

Figure 5. Evolution of triphyllite during hydrothermal and weathering processes; right is $\mathrm{P}_{2} \mathrm{O}_{5}$ versus $\mathrm{FeO} / \mathrm{MnO}$ and left is the REE pattern of triphylite.

Table 3. Main characteristics of the first group pegmatites hydrothermal and weathering processes.

\begin{tabular}{ccc}
\hline Pegmatite & Hydrothermal process albitization & Weathering process hydratation \\
\hline Spodumene & Petalite + Albite & \\
Ambligonite & Apatite + Brazilianite & \\
Triphyllite & Ferrisicklerite + Heterosite & Rockbrigeite + Beraunite \\
\hline
\end{tabular}

compressive deformation phase Dl. The ten individual zircon crystals within leucogranites are dating $579 \pm 5$ Ma. The very Sr-enriched and Nd-depleted initial ratios $\left(0.782 \leq{ }^{87} \mathrm{Sr}^{86} \mathrm{Sr}_{(\mathrm{i})} \leq 0.823\right.$ and $\left.-8.2 \leq \mathrm{Nd}_{(600)} \leq-7.4\right)$ must be related to an important role of a crustal source. They are linked with Urucum granite in Governador Galileia region $[4,8]$. The sin-tectonic magmatic series are related to crustal melting produced by decompression and thermal relaxation $\left(550^{\circ} \mathrm{C}-700^{\circ} \mathrm{C}\right.$ and $\left.4-5 \mathrm{kbar}\right)$. These perphosphorous leucogranites display porphyritic textures and are characterized by the presence of apatite phenocrystal $(2 \mathrm{~cm})$ and P-rich feldspars. The Plagioclase feldspar in leucogranites varies from $\mathrm{An}_{12}$ to $\mathrm{An}_{0}$ composition and found phosphorus values between 1.0 and $2.5 \mathrm{wt} \% \mathrm{P}_{2} \mathrm{O}_{5}$. Apatite in the leucogranites show two groups based on chemistry and occurrence: the phenocrystal apatite enriched in Mn disseminated within the leucogranites and the small apatite disseminated within plagioclase feldspar where Mn-depleted.

The Medina migmatite belong to Paraíba do Sul Complex and outcrop in all the eastern part of Mantiqueira belt. The Sm-Nd isotopic data for the Paraíba do Sul paragneiss indicate TDM model ages between 1.61 and $1.74 \mathrm{Ga}$, which are interpreted as an upper limit for the sources of the original sediments and deposit during the Meso- or Neoproterozoic [13]. The most abundant variety of the Medina migmatite are leucocratic and mesocratic migmatites. They are occupied a large bands oriented SE-NW in eastern part of Mantiqueira Belt. The leucosome is mainly composed of quartz, plagioclase (An20-31), cordierite, pathetic K-feldspar, biotite and rare sillimanite, and occasional garnet and muscovite. The melanosome comprises alternate granoblastic and restites bands defining a main foliation. They are formed of biotite, quartz, plagioclase (An26-30), garnet, cordierite and rare sillimanite, locally graphite. The apatite, zircon and the small monazite are the main accessory minerals.

Garnet geothermobarometry indicates that the peak anatexis occurred at a c. $800^{\circ} \mathrm{C}$ and c. $4.5 \mathrm{kbar}$. The majority of the dating zircon of the Medina migmatite compound gneisses give an age of $585 \pm 7 \mathrm{Ma}$. They are contemporary of Urucum Suite leucogranites and perphosphorous leucogranites [14,15].

They are highly peraluminous $(1.07<$ ASI $<1.38)$ and, from the porphyritic granites to the aplopegmatitic facies. Their $\mathrm{P}_{2} \mathrm{O}_{5}\left(0.28\right.$ to 1.06 wt\%) decrease with $\mathrm{SiO}_{2}$ increase 72 up to $75 \mathrm{wt} \%$. Very high concentrations of $\mathrm{P}_{2} \mathrm{O}_{5}$ in silicic per-aluminous granites are symptomatic of strong differentiation. In a same way, a decrease of major elements $\left(\mathrm{CaO}, \mathrm{Fe}_{2} \mathrm{O}_{3}, \mathrm{MgO}, \mathrm{TiO}_{2}\right)$ and of trace elements ( $\mathrm{Zn}, \mathrm{V}, \mathrm{Sc}, \mathrm{Co}, \mathrm{Cr}, \mathrm{Ni}, \mathrm{REE})$ is observed from the Medina Migmatites, Urucum granites Suite to the aplopegmatites. The $\mathrm{MgO} / \mathrm{TiO}_{2}$ ratio nears 3, which may be compared to the typical granites of crustal origin. The perphosphorous leucogranites are linked with Urucum granite Suite and migmatites suites in eastern of Minas Gerais state. The plots of $\mathrm{P}_{2} \mathrm{O}_{5}$ versus $\mathrm{SiO}_{2}$ show a regu- 
lar variation the $\mathrm{P}_{2} \mathrm{O}_{5}$ in the granite decreases at $\mathrm{SiO}_{2}$ (72\%) from this point onwards $\mathrm{P}_{2} \mathrm{O}_{5}$ increases (Figure 6). These perphosphorous leucogranites and pegmatites are characterized mineralogically by the presence of rare phosphates (amblygonite, triphyllite, triplite, brazilianite). The trend is related to the later stages of magmatic differentiation. The $\mathrm{P}_{2} \mathrm{O}_{5}$ is concentrated in the late magmatic stage with $\mathrm{Rb}, \mathrm{Li}$ and shows a negative correlation with $\mathrm{CaO}$. The $\mathrm{Ca}$ activity may be influenced the apatite solubility.

The Medina migmatites are a peraluminous compositions with a presence of the normative corundum indicate a metasedimentary source. However, the medina migmatites trend seems to be compatible with the presence of restitic apatite. We observed in restitic biotite the small apatite and zircon inclusions. The phosphorus enrichment and discrete variation of the major and some trace elements content would be associated to restite unmixing during the segregation of anatectic melt variable melting degree of plagioclase and crystallization of microcline and micas.

Smoler 1987 [16] and Häussinger 1990 [17] have used correlations between $\mathrm{Al}_{2} \mathrm{O}_{3}, \mathrm{TiO}_{2}$ and $\mathrm{Zr}$ to discriminated shales and sandstones and have identified lithostratigraphic units in metamorphosed belts. The Medina Migmatites are binary mixing between shales and sandstone with high part immature sandstones in Al-Ti-Zr diagram (Figure 6). The trend of leucogranites extending in opposite direction linked to early crystallisation zircon and ilmenite and the solubility of these phases is very low under hydrous conditions and low temperature, it's a case for the leucogranites suite their temperature of crystallisation is between $550^{\circ} \mathrm{C}$ and $700^{\circ} \mathrm{C}$. The immature sandstones are potentially as fertile sources as leucogranites and melting and restite segregation are an important pro- cess in genesis of peraluminous granites.

The REE patterns show tow groups (Figure 7), one has the higher REE-contents, less fractionated pattern, flattening through the intermediate and heavy REE, and a conspicuous positive $\mathrm{Eu}$ anomaly. The second group is the most fractionated, has the lowest HREE and small Eu anomaly. The variable quantities of apatite, zircon, and garnet are responsible for the higher intermediate and heavy REE contents. The different intensities of $\mathrm{Eu}$ anomaly are likely to be related to variations in the partial melting degree of the metasedimentary source rocks.

The geochemical data of the Medina Migmatites show a peraluminous composition and high part of immature sandstones. The Medina Migmatites are potential sources of genesis the leucogranites suite. The peak anatexis of migmatites calculated with garnet geothermobarometry indicates a high temperature $\left(800^{\circ} \mathrm{C}\right)$ and the leucogranitic melting involved at low temperature $\left(550^{\circ} \mathrm{C}-700^{\circ} \mathrm{C}\right)$ explained a geochemical trend of leucogranites suites (Figure 8). The distribution and behaviour of the many traces elements show a strong implication of the Paraíba do Sul metasediments source rocks in genesis of leucogranites suites.

\section{Conclusion}

The geochemical parameters of the P-Li-Be bearing pegmatites of the first group show the same trend fractionation, as suggested by the mineralogical composition. The variation of tourmaline and columbite-tantalite composition of the first group game again applies a change of melt composition during the regional development of the pegmatites. A systematic compositional trend seems to suggest a petrogenetic link between the pegmatites of the region. The $\mathrm{Fe} / \mathrm{Mn}$ ratio of tourmaline in samples of the first group shows the same behavior as in columbite-

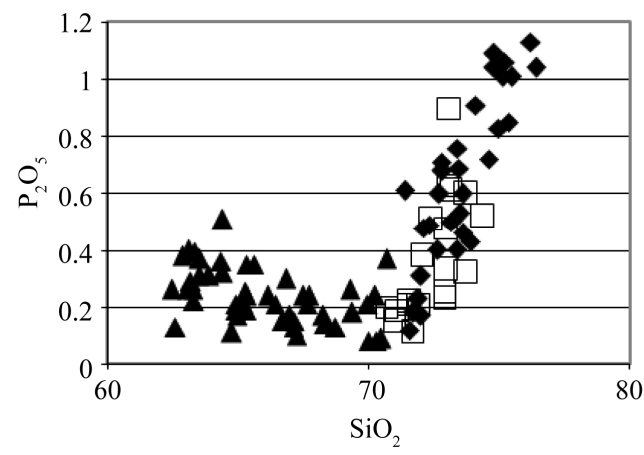

(a)

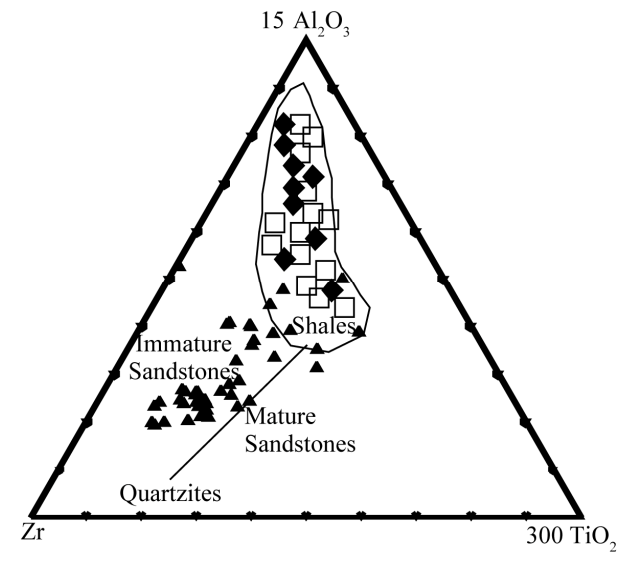

(b)

Figure 6. Distribution of the perphosphorous leucogranites (P), Urucum Suite (Ur) and Medina migmatites $(\mathrm{Mig})$ in the $\mathrm{P}_{2} \mathrm{O}_{5}$ versus $\mathrm{SiO}_{2}$ diagram (a) and the Al-Ti-Zr diagram (b). In (b) show the positions of the immature and mature sandstones, quartzite and shale's, and the solids contours correspond to the field of peraluminous granites in word. 


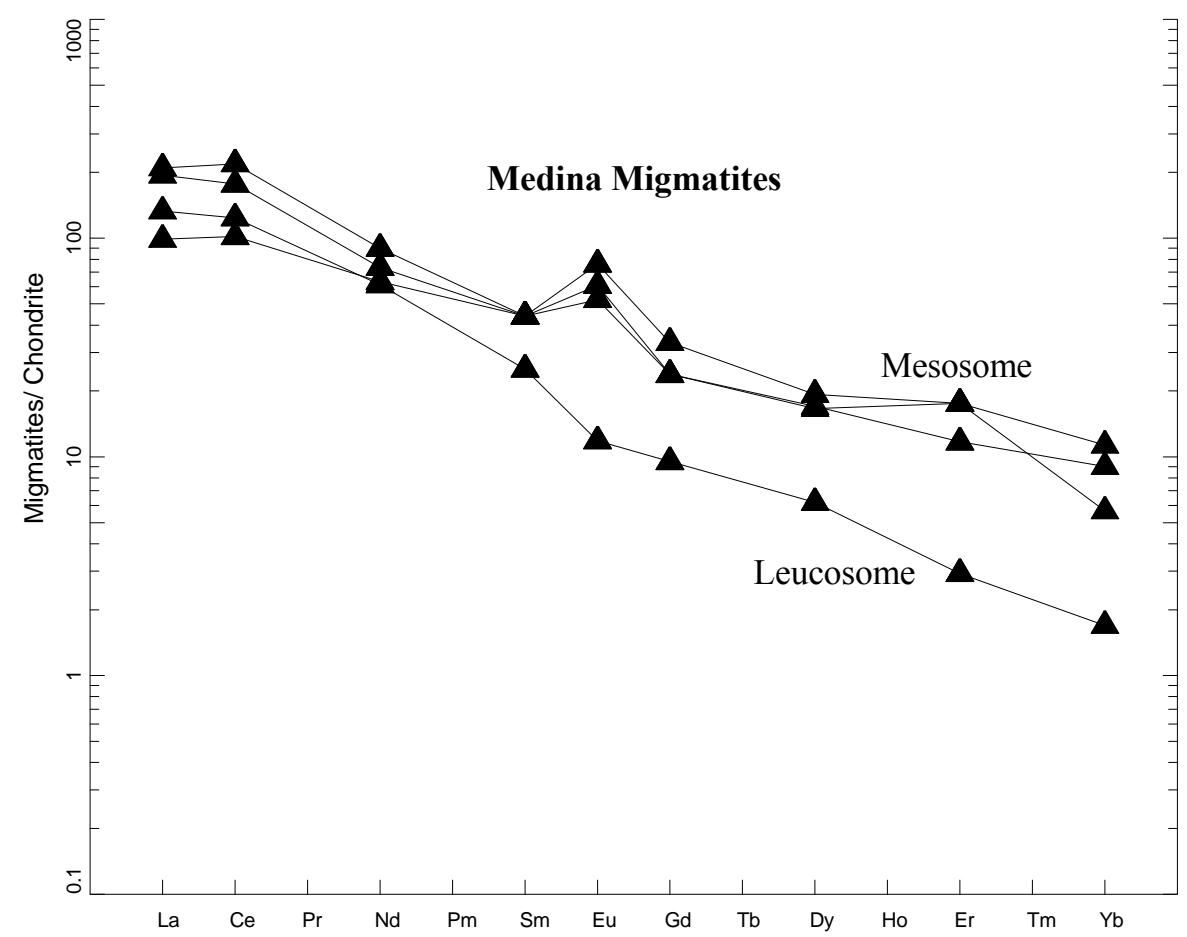

Figure 7. Distribution of the perphosphorous leucogranites (P), Urucum Suite (Ur) and Medina migmatites (Mig) in the REE patterns diagram.

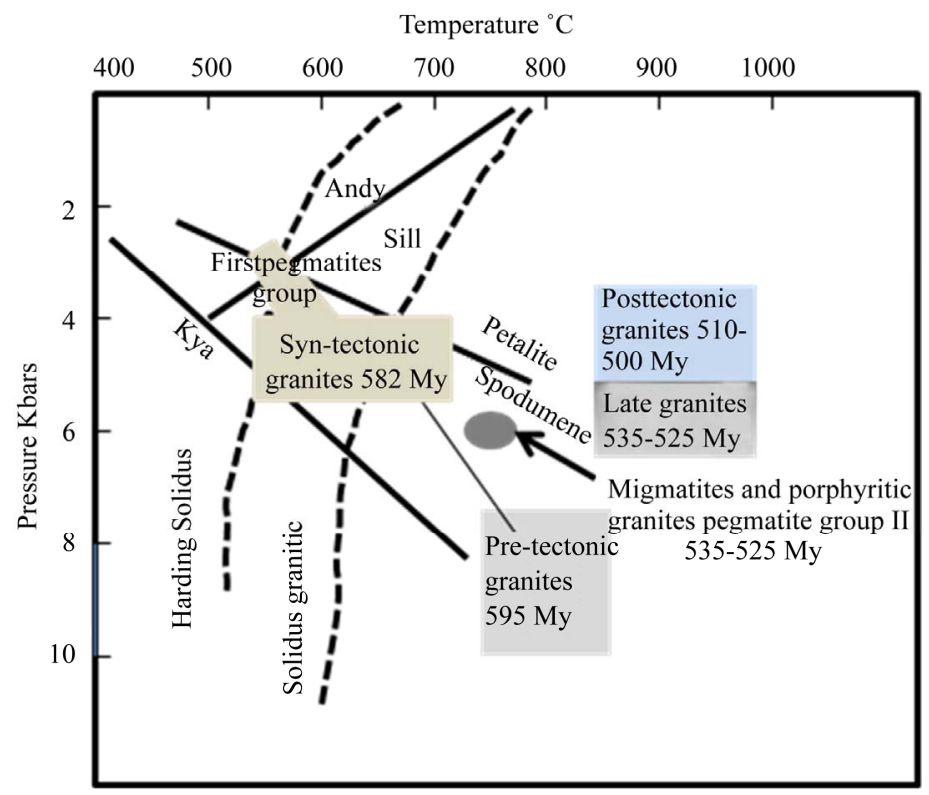

Figure 8. Compilation of the P-T-t Neoproterozoic granites of the Minas Gerais [2,5]. The pre-tectonic granites (595 My) are exhumed during a main deformation phase D1 (590 - $565 \mathrm{My}$ ) corresponding to a collisional event. The sin-tectonic and the $\mathrm{P}-\mathrm{Li}$-Be bearing pegmatites have an age of $582 \mathrm{My}$. The late and post-tectonic granitoids and the $2^{\text {nd }}$ pegmatites group $(537$ $520 \mathrm{My}$ ) are contemporaneous with the second phase of deformation D2 that corresponds to extensional movements. The post-tectonic granitoids were emplaced in the upper crust, 511 to $500 \mathrm{My}$.

tantalite and garnets. The simple pegmatites are transiting north in the gem-rich pegmatites. The Fe/Mn ratio not only shows qualitatively the fractionation index, the degree of regional development, but also the internal de- velopment of the body. The ratio shows a negative correlation with lithium. The $\mathrm{Co}, \mathrm{Zn}$ and $\mathrm{Nb}$ contents are rising at first group, but falling when starting crystallization of garnet, columbite-tantalite, and Behierit. 


\section{REFERENCES}

[1] C. P. Pinto, "Projeto Leste-MG. Relatorio Integrado CPRM," 1997.

[2] E. Bilal, A. H. Horn, H. A. Nalini, J. M. Correia-Neves, A. Giret, J. Moutte, K. Fuzikawa, M. L. S. Fernandez and F. M. de Mello, "The Neoproterozoic Granitoid Suites in South-Easthern Brazil," Special Issue Revista Brasileira de Geocience, Vol. 30, No. 1, 2000, pp. 51-54.

[3] E. Bilal, A. H. Horn and J. Moutte, "Zur Mineralogie und chemischen Zusammensetzung der Pegmatite in Ostbrasilien," Münchener Geologische Hefte, Vol. A28, 2000, pp. 91-97.

[4] H. A. Nalini, E. Bilal, J. M. Correia-Neves and M. A. Carneiro, "Evidence of the Crustal Contribution from the Typological of Zircons in the Granitic of Mddio Rio Doce Region, Minas Gerais," Proceeding of the 39th Congress Brazil Geology, Salvador, Vol. 6, 1996, pp. 418-420

[5] E. Bilal, H. Horn, H. A. Nalini, J. M. Correia-Neves and F. M. Mello, "Evolução Magmatica das Suites Granitoides Proterozoicos do Setor Setentrional Província Estrutural Mantiqueira, Minas Gerais, Espírito Santo, Brasil," Geonomos, Vol. 8, No. 1-2, 2001, pp. 77-86.

[6] E. Bilal, A. H. Horn, H. A. Nalini, J. M. Correia-Neves, A. Giret, K. Fuzikawa and M. L. S. Fernandez, F. M. de Mello and J. Moutte, "Neoproterozoic Granitoid Suites of Rio Doce Region, Brazil," International Conference on Precambrian and Craton Tectonics, Ouro Preto, 1998, pp. 41-43.

[7] A. C. Pedrosa-Soares, C. Wiedernann, M. L. S. Fernandes, L. F. Faria and J. C. H. Ferreira, "Geotectonic Significance of Die Neoproterozoic Granitic Magmatism in the Araçuaí belt (SE Brazil): Models and Pertinent Questions," Revista Brasileira de Geofísica, Vol. 29, 1999, pp. 59-66.

[8] H. A. Nalini, E. Bilal, J. L. Paquette, C. Pin and R. Machado, "U-Pb Geochronology and Sr-Nd Isotopical Geochemistry of the Galiléia and Urucum Suites the Neoproterozoic Granitoids, Rio Doce Valley, Southeastern Brazil," Comptes Rendus Geoscience of the Paris Academy of Sciences, Vol. 331, 2000, pp. 459-466.

[9] E. Bilal, J. Cesar-Mendes, J. M. Correia-Neves, M. Nas- raoui and K. Fuzikawa, "Chemistry of Tourmalines in Some Pegmatites of São José da Safira Area, Minas Gerais, Brazil," Journal of the Czech Geological Society, 1998, Vol. 43, No. 1-2, pp. 33-38.

[10] J. César-Mendes, E. Bilal, J. M. Correia-Neves and A. Giret, "As Turmalinas de Pegmatitos da Região de São José da Safira, Estado de Minas Gerais," 38th Cong. Bras. Geol., Balneário Camboriú. Bol. Res. Expand. Balneário Camboriú, SBG, Vol. 1, 1994, pp. 204-205.

[11] E. Bilal, J. César-Mendes and J. Correia-Neves, "The Columbo-Tantalite Bearing the Pegmatites from São José da Safira Region, Minas Gerais," Proceeding of the 38th Brazilian Geology Congress, Camboriú, Vol. 1, 1984, pp. 198-199.

[12] F. M. de Mello and E. Bilal, "The Perphosphorous Leucogranites of the Minas Gerais State, Brazil," Romanian Journal of Mineral Deposits, Vol. 81, 2004, pp. 140-143.

[13] J. J. Celino, "Variação Compositional em Suites de Granitóides Neoproterazóicos e sua Implicação na Evolução do Orógeno Aruçuaí (Brasil)—Oeste Congolês (Africa)," Ph.D. Thesis, Instituto de Geociências, Universidade de Brasilia, Brasília, 1999.

[14] E. Bilal, H. Horn, H. Nalini Jr., F. M. de Mello, J. M. Correia-Neves, A. Giret, J. Moutte, K. Fuzikawa and M. L. Fernandes, "The Neoproterozoic Granitoid Suites in Southeastern Brazil," Revista Brasileira de Geocience, Vol. 30, No. 1, 2000, pp. 51-54.

[15] E. Bilal, H. Horn, V. R. O. P. Marciano, M. L. Fernandes, J. M. Correia-Neves, K. Fuzikawa, J. Moutte, F. M. de Mello and M. Nasraoui, "The Chemitry of Pegmatites in the Southeastern Brazil," Special Issue of Revista Brasileira de Geocience, Vol. 30, No. 1, 2000, pp. 234-237.

[16] M. Smoler, "Petrographishe, Geochemische und Phasenpetrologische Untersuchungen an Metasedimenten des NW Spessart, Bayern," Ph.D. Disertation, University of Würzburg, Würzburg, 1987.

[17] H. Häussinger, "Geochemische und Petrologische Untersuchungen an Metasedimentären Nebenges Teinen und Assoziierten Metabasiten der Sulfide Rzvorkommen von Gorob, Damara Orogen, Namibia," Ph.D Disertation, University of Würzburg, Würzburg, 1990. 